\title{
Management of Sorghum [Sorghum bicolor (L.) Moench] Seed Mycoflora by Means of Bio-agents in vitro
}

\author{
Sonal Vaja ${ }^{1 *}$, Nikunj Sohaliya ${ }^{1}$ and Bipin Vahunia ${ }^{1}$ \\ 1Department of Plant Pathology, N. M. College of Agriculture, Navsari Agricultural \\ University, Navsari, Gujarat 396 450, India \\ *Corresponding author
}

\section{Keywords}

Sorghum, Seed mycflora, Biocontrol agents, in vitro

Article Info

Accepted:

25 May 2018

Available Online:

10 June 2018
Sorghum [Sorghum bicolor (L.) Moench] is a vital life-sustaining food crop for human being as well as for livestock in many parts of world. In India, Maharashtra, Karnataka, Andhra Pradesh, Madhya Pradesh, Gujarat and Tamil Nadu are major sorghum growing states. Therefore, investigation was undertaken during 2016 at N. A. U., Navsari on isolation of sorghum seed infecting fungi, (Colletotrichum sp., Fusarium moniliforme, Alternaria alternata, Curvularia lunata, Macrophomina sp., Aspergillus niger and A. flavus.) and symptomatology induced by these seed infecting fungi, affect on seed quality, loss of seed germination and seedling vigour. Therefore seeds are treated with bio-control agents. All the tested bio-control agents were found significantly superior in inhibiting the mycelial growth of the pathogen over control. Among them seed treated with Trichoderma viride recorded highest seed germination $(83.00 \%)$ and shoot length $(7.10$ $\mathrm{cm})$. The maximum root length recorded in Trichoderma harzianum $(6.90 \mathrm{~cm})$ and maximum seedling vigour index recorded in Pseudomonas fluorescens (1137.60).

\section{Introduction}

Sorghum is known to suffer from more than 30 fungal diseases (USDA, 1960). Important seed borne fungal diseases recorded on sorghum are stalk rot, target spot, stalk rot/ anthracnose/red leaf, seed rot/stalk rot, seedling blight/charcoal rot and covered smut/grain smut (Richardson, 1990). Among them, the grain infecting molds have become a major constraint of early maturing high yielding hybrids and improved varieties that are grown during the rainy season (Thakur et al., 2006). These losses in potential yield, mold fungi which grow on the seed substratum produce mycotoxins which are hazardous to man and animals (Halt, 1994). Seed is the most important input for crop production. Pathogen free healthy seed is urgently needed for desired plant populations and good harvest. Though the regular fungicides used for seed treatment are found to inhibit growth of the seed borne pathogens and their role in improvement of seed quality is poorly understood (Raju et al., 1999). Seed treatment for controlling plant diseases has been termed as the "pain less method" for farmers. In under developing country like 
India, it is all the more important since we cannot pay the heavy costs of spraying and dusting. Biological control of plant pathogens using antagonistic microorganisms is a vital area of plant pathological research in the present day strategy of avoiding environmental pollution. In the present study efforts were made to develop strategies for the management of seed borne fungi and to enhance the germination and seedling vigour. Therefore, the present investigation was undertaken to find out the mycoflora associated with the seeds of sorghum and to evaluate the efficiency of bio-agents against seed mycoflora and seed germination of sorghum.

\section{Materials and Methods}

\section{Experimental location}

The research experiment was conducted in Department of Plant Pathology, N. M. College of Agriculture, Navsari agricultural University, Navsari during 2015-16. Determine the antagonistic activity of different bio-control agents against Sorghum seed mycoflora by blotter paper method

\section{Isolation of pathogen}

Detection of fungi associated with sorghum seeds were carried out by taking 100 seeds through standard blotter paper method and PDA plate method. Ten seeds each of nonsurface sterilized and surface sterilized by $1 \%$ Sodium hypochloride $(\mathrm{NaOCl})$ solution for one minute were placed at equal-distance on three layers of properly moistened sterilized blotters and petri plates. These were incubated under $12 / 12 \mathrm{hr}$ alternating light and dark period at $25 \pm 2^{\circ} \mathrm{C}$. Developing fungal growth on each of the seed were observed regularly and identified by microscopic observations. Isolation was carried out by inoculating the detected mycoflora by standard agar plate method. These cultures were further purified by single spore isolation method. These pure culture isolates were maintained on PDA slants in refrigerator at $5 \pm 2 \mathrm{oC}$ temperature. The streptomycin was added after autoclaving the media to avoid bacterial contamination.

\section{Efficacy of bio-control agents against Sorghum seed mycoflora in vitro}

The following materials were used during the present investigations:

\section{Bio-control agents}

Trichoderma viride Pers, ex. grey NAU isolate, Trichoderma harzianum Rifai. NAU isolate, Trichoderma koningii Oudem, Pseudomonas fluorescens Migula NAU isolate and Bacillus subtilis Ell NAU isolate.

\section{Methods}

Different bio-agents were evaluated to check their effect on germination and vigour index of seeds inoculated with isolated fungi. For this healthy seeds of sorghum variety GJ-42 were inoculated with the mixture of all isolated fungus by soaking the seeds into mixed spore suspension of fungi and then treated with all respective bio-agents. These treated seeds were evaluated by paper towel method (Khare, 1996) and incubated at $27 \pm 2^{\circ}$ $\mathrm{C}$ for 10 days. After ending of incubation period observations were recorded as number of germinated seeds, shoot length and root length to calculating vigour index and germination percentage.

\section{Results and Discussion}

\section{In vitro testing of bio-control agents}

The results presented that Different bio-agents (Table 1) were tested to check their effect on seed germination and seedling health of 
sorghum seeds variety GJ-42 inoculated with mixture of all isolated fungi. Data presented in the Table 1 and graph revealed significant effect of all bio-agents on seed germination shoot length, root length and seedling vigour index. Overall, bio-agents recorded 23.64 to $50.91,45.83$ to 97.22 and 56.61 to $98.28 \%$ increase in seed germination, shoot length and root length, respectively over control.
Seed treated with Trichoderma viride recorded highest seed germination $(83.00 \%)$ which was at par with Trichoderma harzianum (80.00\%) and Trichoderma koningii (77.00\%). Whereas, in Pseudomonas fluorescens and Bacillus subtilis, recorded 72.00 and $68.00 \%$ seed germination, respectively.

Table.1 Screening of known antagonists as bio-agents to control of sorghum seed borne fungi in vitro

\begin{tabular}{|c|c|c|c|c|c|c|c|c|}
\hline Treatment & Conc. & $\begin{array}{c}\text { Seed } \\
\text { germination } \\
(\%)^{*}\end{array}$ & $\begin{array}{c}\text { Increase in seed } \\
\text { germination } \\
\text { over control } \\
(\%)\end{array}$ & $\begin{array}{l}\text { Shoot length } \\
\text { (cm)* }\end{array}$ & $\begin{array}{c}\text { Increase in } \\
\text { shoot length } \\
\text { over control } \\
(\%)\end{array}$ & $\begin{array}{c}\text { Root } \\
\text { length } \\
(\mathrm{cm}) *\end{array}$ & $\begin{array}{l}\text { Increase in } \\
\text { root length } \\
\text { over control } \\
(\%)\end{array}$ & $\begin{array}{c}\text { Seedling } \\
\text { Vigour Index } \\
\text { (SVI) }\end{array}$ \\
\hline $\begin{array}{l}\text { Trichoderma viride Pers, ex. } \\
\text { Grey NAU isolate }\end{array}$ & $0.4 \%$ & 83.00 & 50.91 & 7.10 & 97.22 & 6.65 & 91.09 & 880.70 \\
\hline $\begin{array}{l}\text { Trichoderma harzianum Rifai. } \\
\text { NAU isolate }\end{array}$ & $0.4 \%$ & 80.00 & 45.45 & 6.95 & 93.06 & 6.90 & 98.28 & 1108.00 \\
\hline Trichoderma koningii Oudem & $0.4 \%$ & 77.00 & 40.00 & 6.73 & 86.81 & 6.23 & 78.88 & 998.70 \\
\hline $\begin{array}{l}\text { Pseudomonas fluorescens } \\
\text { Migula NAU isolate }\end{array}$ & $0.5 \%$ & 72.00 & 30.91 & 6.30 & 75.00 & 6.60 & 89.66 & 1137.60 \\
\hline $\begin{array}{l}\text { Bacillus subtilis Ell NAU } \\
\text { isolate }\end{array}$ & $0.5 \%$ & 68.00 & 23.64 & 5.25 & 45.83 & 5.45 & 56.61 & 770.50 \\
\hline Absolute control & - & 55.00 & 0.00 & 3.60 & 0.00 & 3.48 & 0.00 & 389.50 \\
\hline S. Em \pm & & 2.59 & - & 0.11 & - & 0.12 & - & 28.54 \\
\hline CD $0.05 \%$ & & 7.70 & - & 0.34 & - & 0.37 & - & 84.78 \\
\hline $\mathrm{CV} \%$ & & 7.15 & - & 5.98 & - & 6.63 & - & 9.16 \\
\hline
\end{tabular}

*Average of three repetitions and 25 seeds each repetition

Graph.1 Screening of known antagonists as bio-agents on sorghum seed germination, shoot length, root length and seedling vigour index in vitro

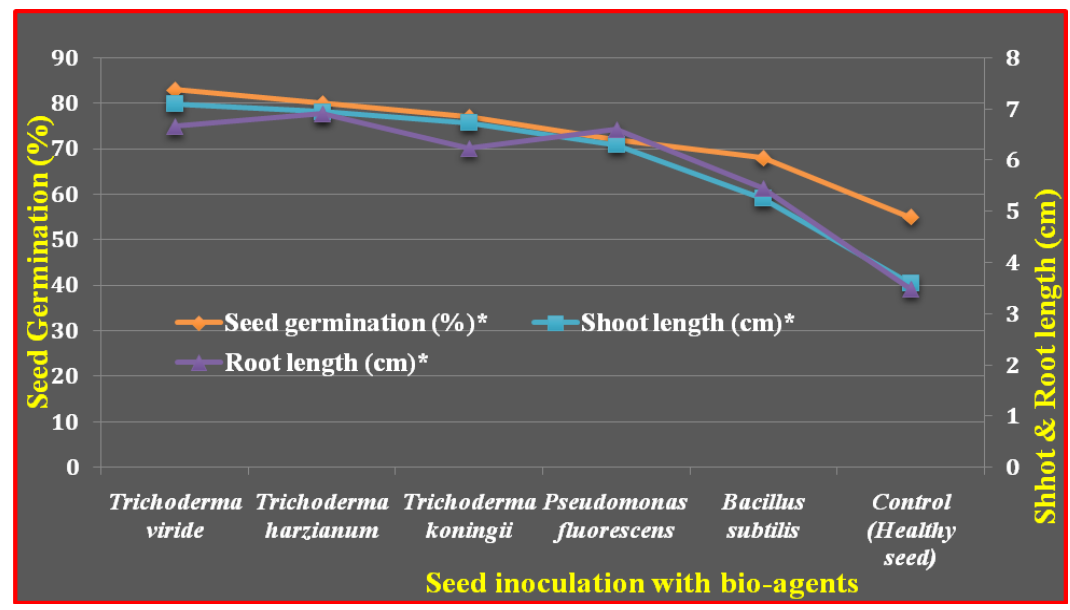


The result in term of shoot and root length with seedling vigour index, all the treatments showed larger shoot length, root length and seedling vigour index as compared to control. Seed bio-priming with $T$. viride recorded maximum shoot length $(7.10 \mathrm{~cm})$ which was at par with $T$. harzianum $(6.95 \mathrm{~cm})$.

The maximum root length recorded in $T$. harzianum $(6.90 \mathrm{~cm})$ which was at par with $T$. viride $(6.65 \mathrm{~cm})$. The maximum seedling vigour index recorded in Pseudomonas fluorescens (1137.60) which was at par with T. harzianum (1108.00). Similarly, B. subtilis recorded $5.25 \mathrm{~cm}, 5.45 \mathrm{~cm}$ and 770.50 , shoot length, root length and seedling vigour index, respectivrly and $P$. fluorescens recorded 6.30 $\mathrm{cm}$ shoot length and $6.60 \mathrm{~cm}$ root length as compared to control $(3.60 \mathrm{~cm}, 3.48 \mathrm{~cm}$ and 389.50).

From this study, it is clear that Trichoderma harzianum and Trichoderma viride were found effective in reducing the seed mycoflora in Sorghum. Our result are harmony with earlier worker Elad et al., (1986) that Trichoderma harzianum inhibited linear growth and microsclerotia production of M. phaseolina in vitro and also Alagarsamy and Sivaprakasam (1988) found that Trichoderma viride was capable of checking the growth of $M$. phaseolina in vitro.

\section{References}

Alagarsamy and Sivaprakasam (1988). Effect of antagonists in combination with carbendazim against Macrophomia phaseolina infection in cowpea. $J$. Biol. Control. 2(2): 123-125.

Elad, Y. Vieli, Y., and Chet, I. (1986). Biological control of Macrophomina phaseolina (Tassi.) Goid. by Trichoderma harzianum. Crop Prot. 5: 282-292.

Halt, M. (1994). Aspergillus flavus and aflatoxin B1 in flour production. Eur. J. Epidermiol., 10(5): 555-558.

Khare, M. N. (1996). Methods to test seeds for associated fungi. Indian Phytopath, 49(4): 319-328.

Raju, N. S., Niranjana, S. R., Janardhana, G. R., Prakash, H. S., Shekar, S. H., Mathur, S.B., (1999). Improvement of seed quality and field emergence of Fusarium moniliforme infected sorghum seeds using biological agents. J. Sci. Food Agric. 79:206 212.

Richardson, M. J. (1990). An annotated list of seed borne diseases. Int. Seed Test. Assoc. Zurich, Switzerland.

Thakur, R. P., Rao, V. P., Agarkar, G. D., Bharthi, B., Solunke, R. B. and Navi, S. S. (2006). Variation in occurrences and severity of major sorghum grain mold pathogen in India. Indian Phytopath., 59 (4): 410-416.

USDA. (1960). Index of Plant disease in the United States. Agricultural hand book. 165: (187-211).

\section{How to cite this article:}

Sonal Vaja, Nikunj Sohaliya and Bipin Vahunia. 2018. Management of Sorghum [Sorghum bicolor (L.) Moench] Seed Mycoflora by Means of Bio-agents in vitro. Int.J.Curr.Microbiol.App.Sci. 7(06): 3515-3518. doi: https://doi.org/10.20546/ijcmas.2018.706.412 